\title{
Agronomic Characters of Hulless Barley Collection
}

\author{
Gubanova Vera Mikhailivna \\ Associate Professor of the Department of Production, \\ Storage and Processing of Crop Products \\ Federal State Budgetary Educational Institution of higher \\ Education, Northern Trans-Ural State Agricultural \\ University \\ Tyumen, the Russian Federation \\ gubanovavm@gausz.ru
}

\author{
Gubanov Mikhail Valerievich \\ Head of the Laboratory of Agricultural Produce Quality of \\ Agrobiotechnological Center \\ Federal State Budgetary Educational Institution of higher \\ Education, Northern Trans-Ural State Agricultural \\ University \\ Tyumen, the Russian Federation \\ Mihail-gubanoff.1987@yandex.ru
}

\author{
Gryaznov Anatoly Alexandrovich \\ Professor of the Department of Technology of Production \\ and Processing of Agricultural Products \\ Federal State Budgetary Educational Institution of Higher Education \\ South Ural State Agrarian University \\ Chelyabinsk, the Russian Federation \\ granal@yandex.ru
}

\begin{abstract}
The research was conducted in 2011-2013 in the northern forest-steppe of the Tyumen region. The vegetation period of hulless barley samples ranged from 63 to 80 days. The samples with the length of stages - seedling-heading - 38-42 days and heading-ripening - 29-33 days produced the yield higher than the standard Omsk bare-grain 1 by $2.9-60.6 \%$. The largest number of samples $(56.6 \%)$ formed the eighth group where protein content was $15.1-17.0 \% ; 30.2 \%$ of the samples appeared to be in the ninth group $(17.1-20.1 \%)$, and $13.2 \%$ - in the seventh $(14.0-14.9 \%)$. The highest average 1000 grain weight was observed in barley samples of the ninth group $(42.8 \mathrm{~g})$. The samples of the eighth group showed a lower characteristic value $(40.3 \mathrm{~g})$ while the samples of the seventh group where protein content was $14.0-14.9 \%$ had the lowest value $(39.9 \mathrm{~g})$. The average starch content in the samples of all groups was at the level of 58.8-60.5\%. The limits of starch variations in barley samples were higher in the seventh group with high protein content. In the same group, the variation range of a trait was much higher $(14.2 \%)$. The grain-unit $\mathrm{g} / \mathrm{cm}^{3}$ increased on average from 6.5 (seventh group) to 6.7 (ninth group). The largest variation range was in the eighth group (2.0). A reliable positive correlation with yielding properties was found in the group with very high protein content (17.1-20.1\%). The highest correlation coefficients were found by interrelations with: protein content $(r=0.400), 1000$ grain weight $(r=0.687)$ and grain-unit $\mathrm{g} / \mathrm{cm}^{3}$ $(r=0.656)$. A reliable negatively-associated relationship was found between the starch content and the yield $(r=-0.382)$. The following samples showed high resistance to stem rust (Puccinia graminis Pers), namely: Local (k-3115, Tajikistan), Local (k3170, Tajikistan), Local (k-3772, Dagestan), Local (k-19709, Denmark), Local (to-21747, Dagestan). By lodging resistance at the level of 9 points, the following samples were distinguished, namely: Local (k-3038, Turkmenistan), Local (k-3165, Tajikistan), Local (k-3938, Mongolia), Buck CDC (k-30173,
\end{abstract}

Canada). In the ninth group with high protein content (17.120.1) the local sample from Tajikistan (K-3770) formed standard starch content $(\mathbf{6 0 . 8 \%})$. The local cultivars from Iran (k-3082) and Georgia (k-838) had the highest 1000 grain weight (52.7-55.5 g).

Keywords - hulless barley, protein, starch, grain-unit.

\section{INTRODUCTION}

The problem of creating new varieties of crops is quite challenging nowadays. Applying new varieties is the milestone in the innovation strategy aimed at the development of crop production in the country [1] including the Northern Urals. To create new varieties it is of great importance to study the source material, particularly, barley.

Barley is an adaptive variety that has been cultivated in Siberia for many years. It has a high ability to make use of natural and climatic resources to ensure high productivity. Due to its biological characteristics (short growing season, drought tolerance), barley can produce yields higher than other crops can, despite the lack of heat and moisture in certain years [2].

Recently, along with chaffy varieties that have been cultivated long since, recognized varieties of hulless barley have appeared in the country. Grain of such varieties is much more nutritious, since they have a high protein load, grain hardness, grain-unit, essential and non-essential amino acids, and vitamins. The increase in the number of acres planted to these particular varieties is hampered by insufficiently high grain productivity. In addition, strong lodging and stem rust may be prominent. In this regard, there is a need to create and 
apply new highly productive varieties of hulless barley with high feed and nutritional qualities [3,4]. For these purposes great importance is given to the study of source material.

The success of creating new varieties, including barley, is largely predetermined by the source material that can be represented as samples of the collection of the All-Russian Research Institute of Plant Industry (VIR), and the material of other breeding institutions [5].

The purpose of research was to select economically valuable samples based on yield capacity, length of the growing season, grain quality, stem rust resistance and stem lodging.

\section{SUBJECTS AND METHODS}

The experiments were carried out in the Northern foreststeppe of the Tyumen region in the study area of the Northern Trans-Ural State Agricultural University in the period of 2011-2013.

The weather conditions during the study years differed both in the amount of precipitation and in the air temperature. In 2011, there was a moisture deficit in May and heavy precipitation in June. In 2012, there was an acute moisture deficit with high temperatures in May, June and July. In 2013, there was a moisture deficit in June and heavy precipitation in July.

The soil is leached chernozem, clayey loamy formed on cover loam with traits typical of the forest-steppe zone of the Trans-Urals. The bulk density in a layer of $0-50 \mathrm{~cm}$ ranges from 1.07 to $1.40 \mathrm{~g} / \mathrm{cm} 3$. The humus content in the layer of 0 $20 \mathrm{~cm}$ is $9.05-9.00 \%$. When getting deeper there is a gradual decrease to $2 \%$. The degree of base saturation varies in profile within limits of $89-92 \%$. The water reserves corresponding to the smallest capacity in a layer of $0-50 \mathrm{~cm}$ reach $185 \mathrm{~mm}$ [6]. Low nitrogen status, medium and high - of phosphorus and high potassium status against the calculated amount of nitrogen fertilizers applied contributed to obtaining the cultivar yield and lines of chaffy barley up to $4 \mathrm{t} / \mathrm{ha}$, hulless barley - up to $2.5 \mathrm{t} / \mathrm{ha}$. The forerunner was annual grasses. The experiment was carried out in accordance with the VIR method [7], a plot area was $1-2 \mathrm{~m}^{2}$, the standard was placed through 20 collection samples.

54 botanical accessions of hulless barley including nudum, coeleste, trifurcatum, violaceum, brevisetum, neogenes, himalayense were defined as the material for study. They were taken from the VIR collection and other NRUs. Omsk baregrain accession 1 recognized in the region was used as a standard.

The content of protein and starch was determined in the Department of Biochemistry and Molecular Biology of Vavilov All-Russian Research Institute of Plant Industry (St. Petersburg) [8].

Stem rust resistance (Puccinia graminis Pers), stem lodging was performed according to the VIR method [7] on a 9-point scale.

\section{RESULTS}

The set of collection samples under study was characterized by different length of the growing season. In general, over the years of research, the growing season varied from 63 to 80 days. Subject to meteorological conditions, the length of the growing season varied significantly over the years. Thus, in 2011 it was 69-100 days, in $2012-50-62$ days and in $2013-63-80$ days (Table 1).

TABLE I. VARYING VEGETATION PERIOD FOR HULLESS BARLEY (20112013)

\begin{tabular}{|c|c|c|c|c|}
\hline \multirow[b]{2}{*}{ Year } & \multirow[b]{2}{*}{ Attribute } & \multicolumn{3}{|c|}{$\begin{array}{l}\text { Length of seedling-heading } \\
\text { period, days }\end{array}$} \\
\hline & & 占 & 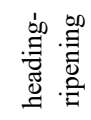 & 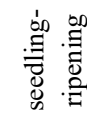 \\
\hline 2011 & $\begin{array}{c}\text { Variation range, days } \\
\text { Variation ratio, } \%\end{array}$ & $\begin{array}{c}33-74 \\
19,7\end{array}$ & $\begin{array}{c}25-50 \\
15,0\end{array}$ & $\begin{array}{c}69-100 \\
8,2\end{array}$ \\
\hline 2012 & $\begin{array}{c}\text { Variation range, days } \\
\text { Variation ratio, } \%\end{array}$ & $\begin{array}{c}25-43 \\
10,7\end{array}$ & $\begin{array}{c}15-25 \\
10,4\end{array}$ & $\begin{array}{c}50-62 \\
4,5\end{array}$ \\
\hline 2013 & $\begin{array}{c}\text { Variation range, days } \\
\text { Variation ratio, } \%\end{array}$ & $\begin{array}{c}30-48 \\
9,4\end{array}$ & $\begin{array}{c}30-40 \\
6,0\end{array}$ & $\begin{array}{c}70-82 \\
3,4\end{array}$ \\
\hline $\begin{array}{l}\text { Avera } \\
\text { ge }\end{array}$ & $\begin{array}{c}\text { Variation range, days } \\
\text { Variation ratio, } \%\end{array}$ & $\begin{array}{c}29-54 \\
13,3\end{array}$ & $\begin{array}{c}25-36 \\
7,7\end{array}$ & $\begin{array}{c}63-80 \\
5,1\end{array}$ \\
\hline
\end{tabular}

Resulting from the research conducted, the samples with the length of seedling-heading period of 38-42 days and heading- ripening period of 29-33 days were singled out. It is with this ratio of the interfacial periods that the yield is higher than the standard by $2.9-60.6 \%$ (Table 2 ).

TABLE II. HIGH-YIELDING HULLESS BARLEY ACCESSIONS WITH THE LENGTH OF VEGETATION PERIOD OF 68-75 DAYS, 2011-2013

\begin{tabular}{|c|c|c|c|c|c|c|}
\hline \multirow{2}{*}{$\begin{array}{l}\text { No. in } \\
\text { VIR } \\
\text { catalog }\end{array}$} & \multirow{2}{*}{$\begin{array}{c}\text { Accessio } \\
\mathrm{n}\end{array}$} & \multirow{2}{*}{$\begin{array}{c}\text { Provenan } \\
\text { ce }\end{array}$} & \multicolumn{3}{|c|}{$\begin{array}{l}\text { Length of seedling- } \\
\text { heading period, days }\end{array}$} & \multirow{2}{*}{$\begin{array}{r}\text { Yield } \\
\text { capaci } \\
\mathrm{y}, \mathrm{g} / \mathrm{m}^{2}\end{array}$} \\
\hline & & & \begin{tabular}{|l|} 
seedling \\
-heading
\end{tabular} & $\begin{array}{l}\text { heading- } \\
\text { ripening }\end{array}$ & $\begin{array}{l}\text { seedling- } \\
\text { ripening }\end{array}$ & \\
\hline 30919 & $\begin{array}{c}\text { Omsk } \\
\text { bare- } \\
\text { grain } 1\end{array}$ & $\begin{array}{l}\text { Omsk } \\
\text { region }\end{array}$ & 39 & 33 & 72 & 307 \\
\hline 3423 & Local & China & 40 & 35 & 75 & 316 \\
\hline 30034 & Shonkin & USA & 41 & 28 & 69 & 493 \\
\hline 30036 & Condor & Canada & 41 & 30 & 71 & 331 \\
\hline 30167 & $\begin{array}{c}\text { CDC } \\
\text { Richard }\end{array}$ & Canada & 38 & 30 & 68 & 355 \\
\hline 30358 & $\begin{array}{c}\text { C.I. } \\
11080 \\
\text { Lan } \\
\end{array}$ & Peru & 42 & 29 & 71 & 378 \\
\hline \multicolumn{3}{|c|}{$\mathrm{HCP}_{05}(\mathrm{n}=54)$} & 2,1 & 0,9 & 1,4 & 40,6 \\
\hline
\end{tabular}

The grain of cultivated hulless barley generally has lower protein content than the grain of wheat. During the analysis of the samples taken from the experimental plots of the agro- 
climatic zones of the Tyumen region, Professor R.I. Belkina (1981-1983) determined that the average protein content in recognized wheat varieties was $16.3 \%$, while in barley varieties it made up $12.8 \%$. To increase the nutritional value of feed, it is proposed to use hulless barley [9].

To range barley samples according to the protein content, groups used by the international CMEA classification system for the genus Hordeum L [10] were taken as the basis, namely: 1 - very low (less than $8.1 \%) ; 2$ - very low $(8.1-9.0 \%) ; 3-$ low $(9.1-10.0 \%) ; 4$ - low $(10.1-12.0 \%) ; 5$ - medium $(12.1-$ $13.0 \%) ; 6$ - medium (13.1-14.0\%); 7 - high (14.1-15.0\%); 8 high (15.1-17.0\%); 9 - very high (more than 17\%).

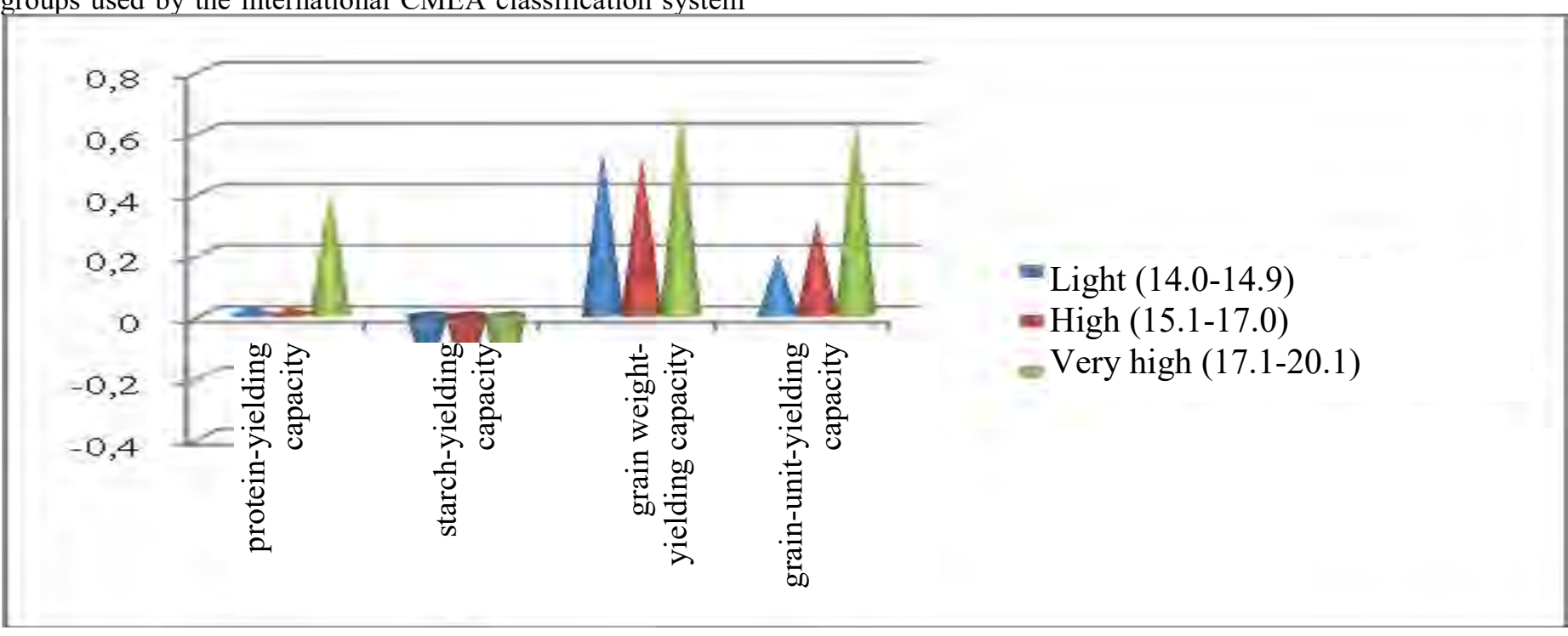

Fig. 1. Crop yield - grain quality relation based on protein content, $\%$

As shown by the data in Table 3, the largest number of samples $(56.6 \%)$ belonged to the eighth group where the protein content was $15.1-17.0 \% ; 30.2 \%$ of the samples formed the ninth group (17.1-20.1\%), and $13.2 \%$ - the seventh (14.0$14.9 \%$ ).

TABLE III. QUALITY OF BARLEY SAMPLES DIFFERENT IN PROTEIN CONTENT, 2011-2013

\begin{tabular}{|c|c|c|c|c|c|c|c|c|}
\hline \multirow{2}{*}{$\begin{array}{l}0 \\
z \\
\vdots \\
0 \\
0\end{array}$} & \multirow{2}{*}{ 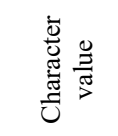 } & \multirow{2}{*}{ 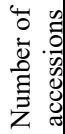 } & \multicolumn{2}{|c|}{$\begin{array}{l}1000 \text { grain } \\
\text { weight, g }\end{array}$} & \multicolumn{2}{|c|}{ Starch, \% } & \multicolumn{2}{|c|}{$\begin{array}{c}\text { Grain-unit, } \\
\mathrm{g} / \mathrm{sm}^{3}\end{array}$} \\
\hline & & & Average & Range & Average & Range & Average & Range \\
\hline 7 & $\begin{array}{c}\text { High } \\
14,0-14,9\end{array}$ & 7 & 39,9 & $\begin{array}{l}31,3- \\
45,5\end{array}$ & 59,5 & $\begin{array}{c}59,5- \\
63,1\end{array}$ & 6,5 & $5,3-7,1$ \\
\hline 8 & $\begin{array}{c}\text { High } \\
15,1-17,0\end{array}$ & 31 & 40,3 & $\begin{array}{c}27,7- \\
51,9\end{array}$ & 60,5 & $\begin{array}{c}58,3- \\
62,9\end{array}$ & 6,6 & $5,2-7,2$ \\
\hline 9 & $\begin{array}{c}\text { Very } \\
\text { high } \\
17,1-20,1\end{array}$ & 16 & 42,8 & $\begin{array}{c}29,4- \\
55,5\end{array}$ & 58,8 & $\begin{array}{c}57,0- \\
60,8\end{array}$ & 6,7 & $5,6-7,4$ \\
\hline
\end{tabular}

The highest average 1000 grain weight was observed in barley samples of the ninth group (42.8 g). In samples of the eighth group, the characteristic value is lower $-40.3 \mathrm{~g}$, and in samples of the seventh group where the protein content is $14.0-14.9 \%$, the indice is lowest $-39.9 \mathrm{~g}$. The variation range of 1000 grain weight is more significant in the groups with very high protein content. The variation range of the character was in groups: $14.2 \mathrm{~g}, 24.2 \mathrm{~g}, 26.1 \mathrm{~g}$, which indicates its significant increase in the groups with a protein content of 17.1 to $20.1 \%$.

The average starch content in all groups is at the level of $58.8-60.5 \%$. The variation range of starch content in barley samples is more significant in the seventh group with high protein content. In the same group, the variation range of the character is much higher $-14.2 \%$. In the eighth and ninth groups, this figure is lower $-4.6 \% ; 3.8 \%$, respectively.

The grain-unit $\mathrm{g} / \mathrm{cm}^{3}$ increased on average from 6.5 (seventh group) to 6.7 (ninth group). The largest variation range was identified in the eighth group (2.0). In other groups, this indice was at the level of $1.8 \mathrm{~g} / \mathrm{cm}^{3}$.

A reliable positive correlation with yield (Fig. 1) was found in the group with very high protein content (17.1$20.1 \%$ ), the highest correlation coefficient was determined by interrelations with: protein content $(\mathrm{r}=0.400), 1000$ grain wight $(\mathrm{r}=0,687)$ and the grain-unit $\mathrm{g} / \mathrm{cm}^{3}(\mathrm{r}=0,656)$. A significant negative relationship was found between the starch content and yield $(\mathrm{r}=-0.382)$. In the group with high protein content of $14.0-14.9 \%$ and $15.1-17.0$, a reliably positive correlation was with 1000 grain weight $\mathrm{r}=0.548$ and $\mathrm{r}=$ 0.520 , respectively. The same relationship was found between yield and grain-unit $\mathrm{g} / \mathrm{cm}^{3}(\mathrm{r}=0.313)$ in the high protein group at the level of 15.1-17.0. In other groups, other indices were insignificant.

For northern regions of Russia, there is a need to create early maturing barley cultivars prone to lodging and standing crop, due to excessive moisture during ripening and harvest, 
tolerant to the most harmful diseases (loose smut, shot hole, powdery mildew, stem rust) that produce annual high yields [11].

In 2012, due to dry summer, no cases of stem rust (Puccinia graminis Pers) had been reported but for some episodic manifestation of this disease. The following accessions showed high pathogenic resilience (Table 4): Local (k-3115, Tajikistan), Local (k-3170, Tajikistan), Local (k3772, Dagestan), Local (k-19709, Denmark), Local (K-21747, Dagestan).

TABLE IV. SOURCES OF STEM RUST AND SHOT HOLE RESILIENCE, 20112013

\begin{tabular}{|c|c|c|c|c|}
\hline $\begin{array}{c}\text { No. in } \\
\text { VIR } \\
\text { catalog }\end{array}$ & Accession & Provenance & $\begin{array}{c}\text { Stem rust, } \\
\text { point }\end{array}$ & $\begin{array}{c}\text { Shot hole, } \\
\text { point }\end{array}$ \\
\hline 30919 & $\begin{array}{c}\text { Omsk bare- } \\
\text { grain 1 }\end{array}$ & Omsk region & 7,7 & 6,3 \\
\hline 3115 & Local & Tajikistan & 9 & 7 \\
\hline 3170 & Local & Tajikistan & 9 & 7 \\
\hline 3772 & Local & Dagestan & 9 & 7 \\
\hline 21747 & Local & Dagestan & 9 & 7 \\
\hline 3423 & Local & China & 9 & 7 \\
\hline 30034 & Shonkin & USA & 9 & 7 \\
\hline 30358 & C.I. 11080 Lan & Peru & 9 & 7 \\
\hline 30440 & 23007 & Denmark & 9 & \\
\hline
\end{tabular}

Plant lodging can significantly reduce the yield, preventing the accumulation of nutrients in the grain. The relationship of lodging resistance with plant productivity was noted by K.V. Azarin, A.V. Usatov, N.S. Kolokolova, O.A. Usatova, A.V. Alabushev, P.I. Kostylev [1], N.A. Surin, N.V. Zobova, N.E. Lyakhova [2], N.I. Aniskov, N.A. Kalashnik, D.V. Garis [3]. A number of works provide information on the relationship of lodging resistance of grain crops with plant height, anatomical structure of the stem and other characters $[4,11]$

TABLE V. LODGING RESISTANCE AND YEILDING CAPACITY OF DIFFERENT-LENGTH BARLEY ACCESSIONS IN VIR CATALOG, 2011-2013

\begin{tabular}{|c|c|c|c|c|}
\hline Group & $\begin{array}{c}\text { Number of } \\
\text { specimens, } \\
\text { pcs }\end{array}$ & $\begin{array}{c}\text { Plant } \\
\text { height, } \\
\mathrm{cm}\end{array}$ & $\begin{array}{c}\text { Lodging } \\
\text { resistance, } \\
\text { point }\end{array}$ & $\begin{array}{c}\text { Yielding } \\
\text { capacity, } \\
\mathrm{g} / \mathrm{m}^{2}\end{array}$ \\
\hline $\begin{array}{c}\text { Very low (41- } \\
60 \mathrm{~cm})\end{array}$ & 29 & 55,0 & $9-7$ & 191 \\
\hline $\begin{array}{c}\text { Short } \\
\text { growing }(61- \\
70 \mathrm{~cm})\end{array}$ & 22 & 65,2 & $9-7$ & 273 \\
\hline $\begin{array}{c}\text { Medium low } \\
(71-80 \mathrm{~cm})\end{array}$ & 2 & 74,7 & $7-5$ & 252 \\
\hline $\begin{array}{c}\text { Medium tall } \\
(81-95 \mathrm{~cm})\end{array}$ & 1 & 84,0 & $7-5$ & 212 \\
\hline
\end{tabular}

All analyzed collection samples, according to the international CMEA classification system for the genus Hordeum L [10], were divided by plant height into 4 groups (Table 5), namely: very low $(41-60 \mathrm{~cm})$, short growing (61-70 $\mathrm{cm})$, medium low $(71-80 \mathrm{~cm})$, medium tall $(81-95 \mathrm{~cm})$.

Negative relationships between plant height and lodging resistance at the medium level were found in the groups: very low $(\mathrm{r}=-0.42 \pm 0.10)$ and short growing $(\mathrm{r}=-0.47 \pm 0.10)$.

The group of short growing samples was distinguished by the highest yield and lodging resistance.

The following samples were distinguished by resistance to lodging: Local (k-3038, Turkmenistan), Local (k-3165, Tajikistan), Local (k-3938, Mongolia), Buck CDC (k-30173, Canada).

Taking into account the high protein content in barley grains intended for feeding purposes, it was advisable to present the characteristics of samples with very high protein content (over 17, 1\% protein) and other attributes. Table 6 shows the samples of the ninth group. All of them have significantly higher protein content compared to that in Omsk bare-grain 1 (exceeding by $2.3-5.3 \%$ ).

TABLE VI. CHARACTERISTIC OF HIGH-PROTEIN SPECIMENS IN VIR CATALOG, 2011-2013

\begin{tabular}{|c|c|c|c|c|c|}
\hline $\begin{array}{c}\text { No. in } \\
\text { VIR } \\
\text { catalog }\end{array}$ & Accession & Provenance & $\begin{array}{c}\text { Protein } \\
, \%\end{array}$ & Starch, \% & $\begin{array}{c}1000 \\
\text { grain } \\
\text { weight, } \mathrm{g} \\
\end{array}$ \\
\hline 30919 & $\begin{array}{l}\text { Omsk bare- } \\
\text { grain } 1\end{array}$ & Omsk region & 14,8 & 60,8 & 47,5 \\
\hline 838 & Local & Georgia & 17,7 & 60,1 & 55,5 \\
\hline 2767 & Komehadaka & Japan & 17,3 & 59,2 & 30,5 \\
\hline 3038 & Local & Turkmenistan & 19,0 & 57,6 & 42,0 \\
\hline 3082 & Local & Iran & 17,7 & 58,7 & 52,7 \\
\hline 3115 & Local & Tajikistan & 17,4 & 58,7 & 44,2 \\
\hline 3165 & Local & Tajikistan & 17,2 & 60,1 & 35,9 \\
\hline 3170 & Local & Tajikistan & 17,1 & 60,8 & 39,2 \\
\hline 3423 & Local* & China & 17,3 & 57,7 & 44,7 \\
\hline 3938 & Local & Mongolia & 20,1 & 57,0 & 29,4 \\
\hline 21747 & Local & Dagestan & 17,9 & 59,3 & 51,5 \\
\hline 27171 & E.E.E.N46 & Bolivia & 18,3 & 56,1 & 32,0 \\
\hline 27176 & $\begin{array}{c}\text { CM67-V- } \\
\text { Sask 1800C }\end{array}$ & Bolivia & 18,2 & 57,3 & 33,6 \\
\hline 27730 & $95683 / 76$ & $\begin{array}{c}\text { Germany (till } \\
1991)\end{array}$ & 17,8 & 59,9 & 45,3 \\
\hline 30250 & Nue grosse & Sweden & 17,7 & 58,8 & 55,1 \\
\hline 30284 & Namoi & Australia & 19,5 & 57,9 & 43,9 \\
\hline 31125 & Nudum 95 & $\begin{array}{l}\text { Chelyabinsk } \\
\text { region }\end{array}$ & 20,0 & 57,0 & 49,8 \\
\hline
\end{tabular}


Local sample from Tajikistan (k-3770) had the starch content at the standard level $(60.8 \%)$. Local varieties from Iran (k-3082) and Georgia (k-838) had the highest 1000 grain weight (52.7-55.5).

\section{CONCLUSION}

1. Over the years of research conducted in conditions of the Northern forest-steppe of the Tyumen region, the vegetation period of hulless barley samples varied from 63 to 80 days. The samples with the length of stages: seedling-heading - 38-42 days and heading-ripening - 2933 days produced the yield higher than the standard Omsk bare-grain 1 by $2.9-60.6 \%$.

2. The largest number of samples $(56.6 \%)$ formed the eighth group where protein content was $15.1-17.0 \% ; 30.2 \%$ of the samples appeared to be in the ninth group (17.1-20.1\%), and $13.2 \%$ - in the seventh (14.0-14.9\%).

3. The highest average 1000 grain weight was observed in barley samples of the ninth group $(42.8 \mathrm{~g})$. The samples of the eighth group showed a lower characteristic value $(40.3$ g) while the samples of the seventh group where protein content was $14.0-14.9 \%$ had the lowest value (39.9 g).

4. The average starch content in samples of all groups was at the level of 58.8-60.5\%. The limits of starch variations in barley samples were higher in the seventh group with high protein content. In the same group, the variation range of a character was much higher (14.2\%).

5. The grain-unit $\mathrm{g} / \mathrm{cm} 3$ increased on average from 6.5 (seventh group) to 6.7 (ninth group). The largest variation range was in the eighth group (2.0).

6. A reliable positive correlation with yielding properties was found in the group with very high protein content (17.120.1\%). The highest correlation coefficients were found by interrelations with: protein content $(\mathrm{r}=0.400), 1000$ grain weight $(\mathrm{r}=0.687)$ and grain-unit $\mathrm{g} / \mathrm{cm} 3 \quad(\mathrm{r}=0.656)$. A reliable negatively-associated relationship was found between the starch content and the yield $(r=-0.382)$.

7. The following samples showed high resistance to stem rust (Puccinia graminis Pers), namely: Local (k-3115, Tajikistan), Local (k-3170, Tajikistan), Local (k-3772, Dagestan), Local (k-19709, Denmark), Local (to-21747, Dagestan).

8. By lodging resistance at the level of 9 points, the following samples were distinguished, namely: Local (k-3038,
Turkmenistan), Local (k-3165, Tajikistan), Local (k-3938, Mongolia), Buck CDC (k-30173, Canada).

9. In the ninth group with high protein content (17.1-20.1) the local sample from Tajikistan (K-3770) formed standard starch content $(60.8 \%)$. The local cultivars from Iran $(\mathrm{k}-$ $3082)$ and Georgia (k-838) had the highest 1000 grain weight (52.7-55.5 g).

\section{References}

[1] K.V. Azarin, A.V. Usatov, N.S. Kolokolova, O.A. Usatova, A.V. Alabushev, P.I. Kostylev, EFFECTS OF SALT STRESS ON ION BALANCE AT VEGETATIVE STAGE IN RICE (ORYZA SATIVA L.), OnLine Journal of Biological Sciences, 2016, Vol. 16, No.1, pp. 76-81.

[2] N.A. Surin, N.V. Zobova, N.E. Lyakhova, GENETIC POTENTIAL AND BREEDING SIGNIFICANCE OF THE BARLEY OF SIBERIA, Vavilov Journal of Genetics and Breeding, 2014, Vol. 18, No. 2, pp. 378-386.

[3] N.I. Aniskov, N.A. Kalashnik, D.V. Garis, FORMATION PROCESS IN F2 HYBRID POPULATIONS WHEN CROSSING CHAFFY AND HULLESS BARLEY ACCESSIONS, Agricultural Biology, 2009, № 3, pp. 79-82.

[4] N.A. Surin, N.V. Zobova, N.E. Lyahova, GENETIC POTENTIAL OF BARLEY IN SIBERIA AND ITS IMPORTANCE FOR BREEDING, Russian Journal of Genetics: Applied Research, 2014, Vol. 4, No. 6, pp. 587-594.

[5] N.I. Vavilov, World plant resources and their use in breeding, Mathematics and natural science in the USSR, M.: -L., 1938, pp. 575595.

[6] D.I. Yeremin, CHANGE IN CONTENT AND QUALITY OF HUMUS DURING AGRICULTURAL USE OF CHERNOZEM OF LEACHED FOREST-STEPPE TRANS-URAL ZONE, Soil science, 2016, No. 5, pp. 584-592.

[7] I.G. Loskutov, O.N. Kovaleva, E.V. Blinova, GUIDELINES ON THE STUDY AND PRESERVATION OF THE WORLD BARLEY AND OAT COLLECTION, SPb., 2012, 63 p.

[8] A.I. Ermakov, V.V. Arasimovich and others, METHODS OF BIOCHEMICAL RESEARCH OF PLANTS, L .: Agropromizdat, 1987,430 p.

[9] M.V. Gubanov, INITIAL MATERIAL FOR SPRING BARLEY BREEDING AND PROSPECTS FOR ITS USE IN THE NORTHERN TRANS-URAL: Thesis for Candidate Degree in Agriculture: 06.01.05 Krasnoyarsk, 2016, 168 p.

[10] the international CMEA classification system for the genus Hordeum L. (subgenus Hordeum), L.: VIR, 1983, 56 p.

[11] O.N. Shupletsova, I.N. Shchennikova, RESULTS OF THE USE OF CELL TECHNOLOGIES IN CREATING NEW BARLEY VARIETIES RESISTANT TO ALUMINUM TOXICITY AND DROUGHT, Vavilov Journal of Genetics and Selection, 2016, Vol. 20, No. 5, pp. 623-628. 